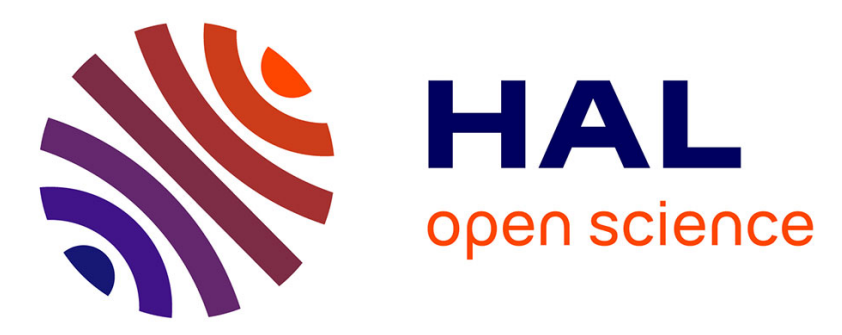

\title{
Comparison of the activities of the lantibiotics nisin and lacticin 3147 against clinically significant mycobacteria
} James Carroll, Lorraine A. Draper, Paula M. O'Connor, Aidan Coffey, Colin Hill, R. Paul Ross, Paul D. Cotter, Jim O'Mahony

\section{- To cite this version:}

James Carroll, Lorraine A. Draper, Paula M. O'Connor, Aidan Coffey, Colin Hill, et al.. Comparison of the activities of the lantibiotics nisin and lacticin 3147 against clinically significant mycobacteria. International Journal of Antimicrobial Agents, 2010, 36 (2), pp.132. 10.1016/j.ijantimicag.2010.03.029 . hal-00601192

\section{HAL Id: hal-00601192 \\ https://hal.science/hal-00601192}

Submitted on 17 Jun 2011

HAL is a multi-disciplinary open access archive for the deposit and dissemination of scientific research documents, whether they are published or not. The documents may come from teaching and research institutions in France or abroad, or from public or private research centers.
L'archive ouverte pluridisciplinaire HAL, est destinée au dépôt et à la diffusion de documents scientifiques de niveau recherche, publiés ou non, émanant des établissements d'enseignement et de recherche français ou étrangers, des laboratoires publics ou privés. 


\section{Accepted Manuscript}

Title: Comparison of the activities of the lantibiotics nisin and lacticin 3147 against clinically significant mycobacteria

Authors: James Carroll, Lorraine A. Draper, Paula M. O'Connor, Aidan Coffey, Colin Hill, R. Paul Ross, Paul D. Cotter, Jim O’Mahony

PII:

DOI:

Reference:

S0924-8579(10)00163-9

ANTAGE 3303

To appear in: International Journal of Antimicrobial Agents

Received date: $\quad 16-2-2010$

Revised date: $\quad 24-3-2010$

Accepted date: $\quad$ 25-3-2010

Please cite this article as: Carroll J, Draper LA, O'Connor PM, Coffey A, Hill C, Ross RP, Cotter PD, O'Mahony J, Comparison of the activities of the lantibiotics nisin and lacticin 3147 against clinically significant mycobacteria, International Journal of Antimicrobial Agents (2008), doi:10.1016/j.ijantimicag.2010.03.029

This is a PDF file of an unedited manuscript that has been accepted for publication. As a service to our customers we are providing this early version of the manuscript. The manuscript will undergo copyediting, typesetting, and review of the resulting proof before it is published in its final form. Please note that during the production process errors may be discovered which could affect the content, and all legal disclaimers that apply to the journal pertain. 


\section{Comparison of the activities of the lantibiotics nisin and lacticin} 3147 against clinically significant mycobacteria

James Carroll ${ }^{a}$, Lorraine A. Draper ${ }^{b}$, Paula M. O'Connor ${ }^{c}$, Aidan Coffey ${ }^{a}$, Colin Hill b,d, R. Paul Ross ${ }^{c, d}$, Paul D. Cotter ${ }^{c, d}$, Jim O'Mahony ${ }^{a, *}$

${ }^{a}$ Department of Biological Sciences, Cork Institute of Technology, Cork, Ireland

${ }^{\mathrm{b}}$ Department of Microbiology, University College Cork, College Road, Cork, Ireland

${ }^{c}$ Moorepark Food Research Centre, Teagasc, Moorepark, Fermoy, Co. Cork, Ireland

${ }^{\mathrm{d}}$ Alimentary Pharmabiotic Centre, Cork, Ireland

ARTICLE INFO

Article history:

Received 16 February 2010

Accepted 25 March 2010

Keywords:

Mycobacteria

Viability

Lantibiotics

AlamarBlue

* Corresponding author. Tel.: +353214326833.

E-mail address: jim.omahony@cit.ie (J. O’Mahony). 


\section{ABSTRACT}

The aim of this study was to use the microtitre alamarBlue assay to investigate and compare the antimycobacterial potential of the lantibiotics nisin and lacticin 3147 against a representative cohort of clinically significant mycobacteria, i.e. Mycobacterium tuberculosis H37Ra, Mycobacterium avium subsp. paratuberculosis (MAP) ATCC 19698 and Mycobacterium kansasii CIT11/06. Lacticin 3147 displayed potent activity against all strains of mycobacteria, with $\mathrm{MIC}_{90}$ values (lowest concentration of lantibiotic that prevented growth of $>90 \%$ of the bacterial population) of $60 \mathrm{mg} / \mathrm{L}$ and $15 \mathrm{mg} / \mathrm{L}$ for $M$. kansasii and MAP, respectively. Lacticin 3147 was particularly effective against $M$. tuberculosis $\mathrm{H} 37 \mathrm{Ra}$, with an $\mathrm{MIC}_{90}$ value of $7.5 \mathrm{mg} / \mathrm{L}$. Nisin, although inhibitory, was generally less potent against all strains of mycobacteria, with $\mathrm{MIC}_{90}$ values of $60 \mathrm{mg} / \mathrm{L}$ for $M$. kansasii and $>60 \mathrm{mg} / \mathrm{L}$ for MAP and M. tuberculosis H37Ra. Thus, lacticin 3147 is a potent antimycobacterial peptide that shows superior activity compared with nisin at physiological $\mathrm{pH}$. 


\section{Introduction}

The extent and diversity of mycobacterial disease is a global problem, impacting significantly both on human and animal health. Mycobacterium tuberculosis is a Gram-positive pathogen that is the main aetiological agent of tuberculosis (TB), and recent statistics from the World Health Organization (WHO) estimate that there were 9.27 million incident cases of TB in 2007 [1].

Furthermore, with an estimated 500000 multidrug-resistant TB (MDR-TB) cases and at least one case of extensively-drug-resistant TB (XDR-TB) reported in 55 countries and territories by the end of 2008 [1], the identification and development of novel antimicrobial compounds is now more important than ever. However, with the exception of rifabutin and rifapentine, no novel drugs have been marketed for TB in the 40 years following the release of rifampicin [2]. An additional worry is the increasing number of pathogenic mycobacteria other than $M$. tuberculosis, which are being implicated as causative agents of disease [3], especially in acquired immune deficiency syndrome (AIDS) patients. One such species, Mycobacterium avium subsp. paratuberculosis (MAP), the aetiological agent of Johne's disease in animals, has caused significant controversy, with reports suggesting its association with Crohn's disease in humans [4-6]. Another mycobacterium, Mycobacterium kansasii, is responsible for serious pulmonary infections and some non-life threatening infections such as septic arthritis [7].

In recent years, an enhanced appreciation of the efficacy of the antimicrobials known as lantibiotics has resulted in their being the focus of much attention as a possible 
alternative to current antibiotic regimens [8-14]. Lantibiotics are gene-encoded, posttranslationally-modified antimicrobial peptides [8] that are distinguished by the unusual lanthionine and/or $\beta$-methyllanthionine residues, dehydrated serines and/or threonines [8]. To date, more than 50 different lantibiotics have been identified with different structures and modes of action [13], and recent comprehensive reviews on lantibiotics have highlighted their potential therapeutic applications [12-14].

Nisin A and lacticin 3147 are two of the most extensively characterised lantibiotics. Nisin is the prototypical lantibiotic and has been approved by the US Food and Drug Administration (FDA) for use in food and veterinary products [15]. Lacticin 3147 differs from nisin by virtue of requiring two peptides for optimal activity, i.e. Ltn $\alpha$ and Ltn $\beta$ (formerly LtnA1 and LtnA2) [16]. Notably, both nisin and lacticin 3147 are active at nanomolar concentrations [16] and can inhibit antibiotic-resistant bacteria [17].

Moreover, both antimicrobials possess more than one mechanism of action in that they inhibit peptidoglycan synthesis as well as forming pores in the membrane of target cells. Both activities are facilitated by binding to the peptidoglycan precursor, lipid II [18-21], which is also a target for some conventional antimycobacterials such as rifampicin that require transportation across the plasma membrane before they can be effective [22]. It is notable that the structure of mycobacterial lipid II differs from all other structures in bacteria investigated to date. This is due to an alternative synthesis pathway as well as modifications both on the $\mathrm{N}$-acetylmuramic acid and peptide side chain components [23]. Peptidoglycan synthesis in mycobacteria is depicted in Fig. 1. 
Whilst nisin has been found to be active against non-pathogenic Mycobacterium smegmatis and Mycobacterium bovis strains [24], neither nisin nor lacticin 3147 have been comprehensively assessed with respect to their antimicrobial activity against clinically significant human and animal mycobacterial pathogens.

\section{Materials and methods}

\subsection{Mycobacterium strains and culture conditions}

Mycobacterium kansasii CIT11/06 (10 days) and M. tuberculosis H37Ra (11 days) were routinely grown at $37^{\circ} \mathrm{C}$ in Middlebrook $7 \mathrm{H} 9 \mathrm{GC}$ broth (MB) (Sigma-Aldrich, Arklow, Co. Wicklow, Ireland) supplemented with glycerol (0.2\%) and $10 \%$ oleic acid-albumin-dextrose-catalase (OADC) (Unitech, Dublin, Ireland). MAP ATCC 19698, also grown in MB containing OADC, was supplemented with $0.2 \%$ mycobactin $\mathrm{J}$ (Synbiotics Europe, Lyon, France) and was incubated at $37^{\circ} \mathrm{C}$ for $8-$ 12 weeks. All strains were stocked in $40 \%$ glycerol and stored at $-80^{\circ} \mathrm{C}$.

\subsection{Preparation of pure lacticin 3147 and nisin $A$}

The lantibiotics were purified as described previously $[17,25]$. In brief, peptides were concentrated via centrifugation and rotary evaporation before being applied to a Phenomenex C12 reversed-phase high-performance liquid chromatography (RPHPLC) column (Phenomenex, Cheshire, UK) equilibrated with 25\% propan-2-ol and $0.1 \%$ trifluoroacetic acid (TFA). The column was subsequently developed in a 
gradient of $30 \%$ propan-2-ol containing $0.1 \%$ TFA to $60 \%$ propan- 2 -ol containing $0.1 \%$ TFA at a flow rate of $1.2 \mathrm{~mL} / \mathrm{min}$.

\subsection{Preparation of mycobacterial cells}

Owing to the slow-growing nature of pathogenic mycobacteria, standard agar and broth minimum inhibitory concentration (MIC) assay methods could not be performed routinely. Thus, the reliable and established microtitre alamarBlue assay was employed [26-28]. Isolates of M. kansasii, MAP and M. tuberculosis were grown in $\mathrm{MB}$ as described above. At log phase, a $10 \mathrm{~mL}$ culture of each mycobacterial strain was centrifuged at 15000 rpm for 20 min using a benchtop centrifuge. Following removal of the supernatant, the pellet was washed in fresh MB and re-suspended in $10 \mathrm{~mL}$ of fresh supplemented MB. The turbidity was adjusted to match a McFarland standard no. $1\left(3 \times 10^{8}\right.$ colony-forming units $\left./ \mathrm{mL}\right)$ with MB. A further 1:20 dilution of the culture was then performed in MB to generate a sufficient volume of culture.

\subsection{Determination of minimum inhibitory concentrations against clinical isolates using the microtitre alamarBlue assay}

Sterile deionised water $(300 \mu \mathrm{L})$ was added to all outer-perimeter wells of a 96 -well plate to minimise evaporation of the medium in the test wells during incubation. In the same 96-well plate, a serial 1:2 dilution of each lantibiotic (lacticin 3147 contained equimolar concentrations of both $\operatorname{Ltn} \alpha$ and $\operatorname{Ltn} \beta$ ) was then performed in $\mathrm{MB}(100 \mu \mathrm{L})$. Final concentrations ranged from $0.11 \mathrm{mg} / \mathrm{L}$ to $60 \mathrm{mg} / \mathrm{L}$ and each dilution series was prepared in triplicate. Positive controls were prepared by adding 
$100 \mu \mathrm{L}$ of the appropriate mycobacterial strain to $100 \mu \mathrm{L}$ of lantibiotic-free broth. Negative controls contained no bacterial cells. Positive and negative controls were also prepared in triplicate. Subsequently, an equal volume of the mycobacterial strain to be assessed was transferred to each well under investigation. The plates were sealed with Parafilm ${ }^{\mathrm{TM}}$ and incubated at $37^{\circ} \mathrm{C}$. Following incubation for 3 days, 7 days and 11 days for M. kansasii, M. tuberculosis and MAP, respectively, $20 \mu \mathrm{L}$ $(10 \%$ of the final volume in the well) of a fresh alamarBlue reagent (AbD Serotec, Oxford, UK) was added to each well and the plates were re-incubated for $24 \mathrm{~h}$, after which time absorbance at $570 \mathrm{~nm}$ and $600 \mathrm{~nm}$ was determined. Subsequent percent reduction values based on alamarBlue conversion were determined using the appropriate formula [29] and the relative growth in each well was compared with that of the positive control. The $\mathrm{MIC}_{90}$ was defined as the lowest concentration of lantibiotic that prevented the growth of $>90 \%$ of the bacterial population relative to the positive control.

\section{Results}

\subsection{AlamarBlue-based minimum inhibitory concentration determination}

AlamarBlue is a redox indicator that yields a colorimetric change in a response to metabolic activity [28]. Relative inhibition of mycobacteria by nisin and lacticin 3147 was assessed by quantifying the absorbance ( $570 \mathrm{~nm}$ and $600 \mathrm{~nm}$ ) of all wells to facilitate the calculation of dye reduction values (\%) using the appropriate formula [29]. Wells that remained blue (i.e. low dye reduction values) were indicative of inhibition of the target strain, whilst wells that turned pink (high dye reduction values) 
were indicative of growth. From these calculated dye reduction values, the relative growth (\%) and corresponding inhibition values were obtained, taking the value of the positive control in each case as $100 \%$. From these values it was possible to determine the $\mathrm{MIC}_{90}$ value. Overall, the relative growth of all test strains varied from $1.2 \%$ to $71.6 \%$ under the experimental conditions examined. To reflect physiological $\mathrm{pH}$, assays were carried out at $\mathrm{pH} 7$.

3.2. $M I C_{90}$ values for nisin and lacticin 3147 against Mycobacterium tuberculosis H37Ra

Mycobacterium tuberculosis H37Ra was the most sensitive strain to lacticin 3147, with an $\mathrm{MIC}_{90}$ value of $7.5 \mathrm{mg} / \mathrm{L}$ (Table 1; Fig. 2). At this concentration, the relative growth of M. tuberculosis was inhibited by $91 \%$. Increasing the lacticin 3147 concentration further resulted in even greater inhibition and culminated in $98.8 \%$ inhibition in the presence of $60 \mathrm{mg} / \mathrm{L}$ lacticin 3147 (the highest concentration employed). Interestingly, lacticin 3147 also exhibited activity at the lowest concentration employed $(0.11 \mathrm{mg} / \mathrm{L})$, where $>50.3 \%$ inhibition was observed.

With respect to nisin, the highest concentration of the lantibiotic used $(60 \mathrm{mg} / \mathrm{L})$ failed to inhibit the pathogen by $90 \%$ and thus the $\mathrm{MIC}_{90}$ value was recorded as $>60$ $\mathrm{mg} / \mathrm{L}$. The assays performed did allow some insight into the sensitivity of the strain to nisin in that it was shown that nisin inhibited $76.3 \%$ of $M$. tuberculosis culture at 60 $\mathrm{mg} / \mathrm{L}$ nisin. At $30 \mathrm{mg} / \mathrm{L}$ nisin, $68.2 \%$ of the $M$. tuberculosis growth was inhibited and subsequent dilutions of nisin established that it is still active at concentrations as low as $0.11 \mathrm{mg} / \mathrm{L}$, as demonstrated by $50.9 \%$ inhibition at this concentration (Fig. 2). 


\subsection{MIC $_{90}$ values for nisin and lacticin 3147 against Mycobacterium kansasii}

\section{CIT11/06}

Of the strains tested, M. kansasii CIT11/06 was the least susceptible to lacticin 3147, with an $\mathrm{MIC}_{90}$ value of $60 \mathrm{mg} / \mathrm{L}$ (Table 1; Fig. 3). Relative growth inhibition was $93 \%$ at this concentration (Fig. 3). Below $15 \mathrm{mg} / \mathrm{L}$, the potency of lacticin 3147 became significantly decreased. However, even at the lowest concentration of lacticin 3147 employed $(0.11 \mathrm{mg} / \mathrm{L})$, activity was still apparent as represented by a $29.2 \%$ inhibition of M. kansasii (Fig. 3).

In comparison, nisin was more active against $M$. kansasii CIT11/06 than the other strains tested, with an $\mathrm{MIC}_{90}$ value of $60 \mathrm{mg} / \mathrm{L}$. At this concentration, $94.5 \%$ inhibition of $M$. kansasii growth was noted. This dropped to $67.5 \%$ inhibition at $30 \mathrm{mg} / \mathrm{L}$ nisin and, as expected, even further for the lower concentrations. However, even at the lowest concentration of nisin tested $(0.11 \mathrm{mg} / \mathrm{L})$, inhibitory activity was still detected (30.3\% inhibition) (Fig. 3).

\subsection{MIC 90 values for nisin and lacticin 3147 against Mycobacterium avium} paratuberculosis ATCC 19698

For lacticin 3147, the $\mathrm{MIC}_{90}$ for MAP ATCC 19698 was $15 \mathrm{mg} / \mathrm{L}$ (90.6\% reduction) (Table 1; Fig. 4). Moreover, $95.2 \%$ and $94 \%$ inhibition of the MAP population was recorded at concentrations of $60 \mathrm{mg} / \mathrm{L}$ and $30 \mathrm{mg} / \mathrm{L}$, respectively, whilst strong inhibition (86\%) was also observed when $7.5 \mathrm{mg} / \mathrm{L}$ lacticin 3147 was utilised (Fig. 4). 
At the lowest concentration employed $(0.11 \mathrm{mg} / \mathrm{L})$, lacticin 3147 successfully inhibited $>50 \%$ of the MAP population.

Although nisin showed quite good efficacy against MAP, $60 \mathrm{mg} / \mathrm{L}$ nisin failed to bring about $90 \%$ inhibition, with inhibition peaking at $81 \%$ (Fig. 4). A decrease in efficacy was seen with lower concentrations of nisin, with moderate activity still apparent at very low concentrations (0.46-0.11 mg/L) (Fig. 4).

\subsection{Comparison of the relative antimycobacterial activities of lacticin 3147 and nisin}

Under these experimental conditions, lacticin 3147 consistently showed superior activity at higher concentrations (Table 1). Mycobacterium tuberculosis was the most susceptible species of mycobacteria, particularly to lacticin, which was $\geq 8$ times more potent than nisin (Fig. 2). Lacticin 3147 brought about as much as $38 \%$ greater inhibition at equivalent concentrations compared with nisin $(7.5 \mathrm{mg} / \mathrm{L})$. Whilst this difference in relative growth remained relatively constant between the concentrations of $15-7.5 \mathrm{mg} / \mathrm{L}$, below $0.93 \mathrm{mg} / \mathrm{L}$ both nisin and lacticin $3147 \mathrm{had}$ an equivalent inhibitory effect against $M$. tuberculosis.

Lacticin 3147 also exhibited superior potency against M. kansasii (Fig. 3), with 31\% less relative growth in the presence of lacticin 3147 compared with nisin (15 mg/L). Although the $\mathrm{MIC}_{90}$ values for both lantibiotics were the same, the general trend of inhibition indicated that lacticin 3147 was more potent. However, at concentrations $<1.8 \mathrm{mg} / \mathrm{L}$, the activity of both lantibiotics was comparable. 
Lacticin 3147 also displayed strong inhibitory activity against MAP, with an $\mathrm{MIC}_{90}$ value $\geq 4$-fold lower than that of nisin (15 mg/L and $<60 \mathrm{mg} / \mathrm{L}$, respectively) (Fig. 4). As with the other two strains, both lantibiotics had similar inhibitory capacity at lower concentrations (e.g. $0.11 \mathrm{mg} / \mathrm{L})$. The greatest difference in percent relative growth between both lantibiotics at equivalent concentrations was seen between $15 \mathrm{mg} / \mathrm{L}$ and $3.75 \mathrm{mg} / \mathrm{L}$. This relative difference remained almost constant over these three concentrations (23.6-24.6\% relative growth).

\section{Discussion}

Antimicrobial peptides are rapidly becoming a realistic alternative therapy, with many peptides showing potent activity against pathogens that has led to their evaluation in clinical trials [30]. Although lantibiotics are traditionally associated with food applications [31], it is evident from the literature that they possess notable levels of activity against clinical pathogens [17,32-36]. However, this study is notable in that it is the first occasion upon which the efficacy of lacticin 3147 against a Mycobacterium $\mathrm{sp}$. has been tested and compared with the activity of nisin. It is also significant that the mycobacteria chosen for this study (which are implicated both in human and animal disease) showed considerable susceptibility to both agents. This study also establishes lipid II as a promising antimycobacterial target and confirms that binding of lantibiotics to the mycobacterial lipid II is not compromised by the extensively modified lipid II structure in mycobacteria [23].

Of the two lantibiotics, lacticin 3147 demonstrated greater potential as a therapeutic agent. This can be attributed to its activity at physiological $\mathrm{pH} 7$, which contrasts with 
that of nisin that is poorly soluble, and thus less active, at this $\mathrm{pH}[8,36]$. The lower activity of nisin at physiological $\mathrm{pH}$ has reportedly also been an issue with respect to its use in the treatment of mastitis-causing pathogens [8]. From the data presented here, it is apparent that lacticin 3147 inhibits mycobacteria at concentrations that are comparable with those of antibiotics currently employed against these pathogens $[37,38]$. These values are in some cases superior to those of the first-line antimycobacterial drug isoniazid that had MIC values of $4-16 \mathrm{mg} / \mathrm{L}$ as determined by Wanger and Mills [37].

Whilst the in vitro efficacy of lacticin 3147 against mycobacteria is encouraging, stability, delivery and in vivo efficacy studies will all need to proceed before the true potential of the lantibiotic as a clinical antimycobacterial can be assessed. The unique ability of some mycobacteria to reside in the phagosomal site within pulmonary macrophages makes their eradication extremely difficult. Moreover, the delivery of antimycobacterial agents that traverse the plasma membrane and maintain stability and activity is rare. However, recent studies have demonstrated that administration of bacteriocins as a complex with liposomes provides a successful mechanism of delivery and inhibition, thus prolonging survival time of mice in an acute TB model [39]. In this context, lantibiotics undoubtedly possess sufficient potential to merit further investigation.

\section{Acknowledgments}

The authors would like to thank Cork University Hospital (Cork, Ireland) for providing the Mycobacterium kansasii strain, Dr Joe Keane (St James' Hospital, Dublin, 
Ireland) for providing $M$. tuberculosis H37Ra and Pierre Douarre for providing the $M$. avium paratuberculosis (MAP) strain.

\section{Funding}

This research was funded by a Strand I research grant from the Technological

Strand Research Program awarded through the Institute of Technology Ireland initiative. JO and PDC are recipients of a Department of Agriculture grant (MAPSAFE).

\section{Competing interests}

None declared.

\section{Ethical approval}

Not required. 


\section{References}

[1] World Health Organization. Global tuberculosis control-epidemiology, strategy, financing. WHO report 2009. Geneva, Switzerland: WHO; 2009. WHO/HTM/TB/2009.411.

[2] Tomioka H, Namba K. Development of antituberculous drugs: current status and future prospects. Kekkaku 2006;12:753-74.

[3] Field SK, Cowie RL. Lung disease due to the more common nontuberculous mycobacteria. Chest 2006;129:1653-72.

[4] Hermon-Taylor J, Bull TJ, Sheridan JM, Cheng J, Stellakis ML, Sumar N. Causation of Crohn's disease by Mycobacterium avium subspecies paratuberculosis. J Gastroenterol 2000;6:521-39.

[5] Scanu AM, Bull TJ, Cannas S, Sanderson JD, Sechi LA, Dettori G, et al. Mycobacterium avium subspecies paratuberculosis infection in cases of irritable bowel syndrome and comparison with Crohn's disease and Johne's disease: common neural and immune pathogenicities. J Clin Microbiol 2007;12:3883-90.

[6] Nacy C, Buckley M. Mycobacterium avium paratuberculosis: infrequent human pathogen or public health threat? August 2008. Washington, DC: American Academy of Microbiology; 2008.

[7] Williams B, Neth O, Shingadia D, Dixon G, Jupp RS, Rosendahl K, et al. Mycobacterium kansasii causing septic arthritis and osteomyelitis in a child. Pediatr Infect Dis J 2010;1:88-9.

[8] Cotter PD, Hill C, Ross RP. Bacterial lantibiotics: strategies to improve therapeutic potential. Curr Protein Pept Sci 2005;6:61-75. 
[9] Parisien A, Allain B, Zhang J, Mandeville R, Lan CQ. Novel alternatives to antibiotics: bacteriophages, bacterial cell wall hydrolases, and antimicrobial peptides. J Appl Microbiol 2008;104:1-13.

[10] Russell JB, Mantovani HC. The bacteriocins of ruminal bacteria and their potential as an alternative to antibiotics. J Mol Microbiol Biotechnol 2002;4:347_ 55.

[11] Gillor O, Nigro LM, Riley MA. Genetically engineered bacteriocins and their potential as the next generation of antimicrobials. Curr Pharm Des 2005;11:1067-75.

[12] Asaduzzaman SM, Sonomoto K, Lantibiotics: diverse activities and unique modes of action. J Biosci Bioeng 2009;5:475-87.

[13] Willey JM, van der Donk WA. Lantibiotics: peptides of diverse structure and function. Annu Rev Microbiol 2007;61:477-501.

[14] Bierbaum G, Sahl HG. Lantibiotics: mode of action, biosynthesis and bioengineering. Curr Pharm Biotechnol 2009;10:2-18.

[15] Delves-Broughton J. Nisin and its application as a food preservative. J Soc Dairy Technol 1990;43:73-6.

[16] Morgan S, O'Connor P, Cotter P, Ross RP. Sequential actions of the two component peptides of the lantibiotic lacticin 3147 explain its antimicrobial activity at nanomolar concentrations. Antimicrob Agents Chemother 2005;49:2606-11.

[17] Piper C, Draper LA, Cotter PD, Ross PR, Hill C. A comparison of the activities of lacticin 3147 and nisin against drug-resistant Staphylococcus aureus and Enterococcus species. J Antimicrob Chemother 2009;64:546-51.

[18] Wiedemann I, Breukink E, van Kraaij C, Kuipers OP, Bierbaum G, de Kruijff B, et al. Specific binding of nisin to peptidoglycan precursor lipid II combines pore 
formation and inhibition of cell wall biosynthesis for potent antibiotic activity. J Biol Chem 2001;276:1772-9.

[19] Breukink E, Wiedemann I, van Kraaij C, Kuipers OP, Sahl H, de Kruijff B, et al. Use of the cell wall precursor lipid II by a pore-forming peptide antibiotic. Science 1999;17:2361-4.

[20] Brötz H, Josten M, Wiedemann I, Schneider U, Götz F, Bierbaum G, et al. Role of lipid-bound peptidoglycan precursors in the formation of pores by nisin, epidermin and other lantibiotics. Mol Microbiol 1998;30:317-27.

[21] Wiedemann I, Bottiger T, Bonelli RR, Wiese A, Hagge SO, Gutsmann T, et al. The mode of action of the lantibiotic lacticin 3147-a complex mechanism involving specific interaction of two peptides and the cell wall precursor lipid II. Mol Microbiol 2006;61:285-96.

[22] Hartmann GR, Heinrich P, Kollenda MC, Skrobranek B, Tropschug M, Weib W. Molecular mechanism of action of the antibiotic rifampicin. Angew Chem Int Ed Engl 2003;24:1009-14.

[23] Mahapatra S, Yagi T, Belisle JT, Espinosa BJ, Hill PJ, McNeill MR. Mycobacterial lipid II is composed of a complex mixture of modified muramyl and peptide moieties linked to decaprenyl phosphate. J Bacteriol 2005;187:2747-57.

[24] Montville TJ, Chung HJ, Chikindas ML, Chen Y. Nisin A depletes intracellular ATP and acts in a bactericidal manner against Mycobacterium smegmatis. Lett Appl Microbiol 1999;28:189-93.

[25] Field D, O'Connor PM, Cotter PD, Hill C, Ross RP. The generation of nisin variants with enhanced activity against specific Gram-positive pathogens. Mol Microbiol 2008;69:218-30. 
[26] Bastian I, Rigouts L, Palomino JC, Portaels F. Kanamycin susceptibility testing of Mycobacterium tuberculosis using Mycobacterium Growth Indicator Tube and a colorimetric method. Antimicrob Agents Chemother 2001;45:1934-6.

[27] Franzblau SG, Witzig RS, McLaughlin JC, Torres P, Madico G, Hernandez A, et al. Rapid, low-technology MIC determination with clinical Mycobacterium tuberculosis isolates by using the microplate alamarBlue assay. J Clin Microbiol 1998;36:362-6.

[28] Carroll J, Douarre P, Coffey A, Buckley J, Cashmen B, O'Farrell K, et al. Optimisation of a rapid viability assay for Mycobacterium avium paratuberculosis (MAP) using alamarBlue. Appl Environ Microbiol 2009;75:7870-2.

[29] alamarBlue ${ }^{\circledR}$ technical datasheet. Oxford, UK: AbD Serotec; 2008. http://www.biokom.com.pl/files/alamarblue.pdf [accessed 22 April 2010].

[30] Zaiou M. Multifunctional antimicrobial peptides: therapeutic targets in several human diseases. J Mol Med 2007;85:317-29.

[31] Cotter PD, Hill C, Ross RP. Bacteriocins: developing innate immunity for food. Nat Rev Microbiol 2005;3:777-88.

[32] Brumfitt W, Salton MR, Hamiliton-Miller JM. Nisin, alone and combined with peptidoglycan-modulating antibiotics: activity against methicillin-resistant Staphylococcus aureus and vancomycin-resistant enterococci. J Antimicrob Chemother 2002;50:731-4.

[33] Davies EA, Bevis HE, Delves-Broughton J. The use of the bacteriocin, nisin, as a preservative in ricotta-type cheeses to control the food-borne pathogen Listeria monocytogenes. Lett Appl Microbiol 1997;24:343-6. 
[34] Severina E, Severin A, Tomasz A. Antibacterial efficacy of nisin against multidrug-resistant Gram-positive pathogens. J Antimicrob Chemother $1998 ; 41: 341-7$.

[35] Rea MC, Clayton E, O'Connor P, Shanahan F, Kiely B, Ross RP, et al. Antimicrobial activity of lacticin 3147 against clinical Clostridium difficile strains. J Med Microbiol 2007;56:940-6.

[36] Galvin M, Hill C, Ross RP. Lacticin 3147 displays activity in buffer against Gram-positive bacterial pathogens which appear insensitive in standard plate assays. Lett Appl Microbiol 1999;28:355-8.

[37] Wanger A, Mills K. Testing of Mycobacterium tuberculosis susceptibility to ethambutol, isoniazid, rifampin, and streptomycin by using Etest. J Clin Microbiol $1996 ; 34: 1672-6$.

[38] Heifets LB, Iseman MD, Lindholm-levy PJ. Ethambutol MICs and MBCs for Mycobacterium avium complex and Mycobacterium tuberculosis. Antimicrob Agents Chemother 1996;40:2483-7.

[39] Sosunov V, Mischenko V, Eruslanov B, Svetoch E, Shakina Y, Stern N, et al. Antimycobacterial activity of bacteriocins and their complexes with liposomes. $J$ Antimicrob Chemother 2007;59:919-25. 
Fig. 1. Schematic cross-section of the mycobacterial cell envelope. The model shows the later stages of Mycobacterium lipid II assembly (right) and synthesis of peptidoglycan from its precursor lipid II. Also shown (left) are the natural modifications (1-5) observed within the mycobacterial lipid II as outlined by Mahapatra et al. [23]. Modifications are seen on the $\mathrm{N}$-acetyl region $\left(\mathrm{COCH}_{3}\right)$ of NAM (1), the carboxyl group of the glutamic acid (2), lysine (3) and the terminal alanine (4) of the pentapeptide. The lipid moiety (Pol-P) is decaprenyl phosphate (5), which differs from the usual lipid moiety (undecaprenyl phosphate) identified in all other bacteria investigated to date.

Fig. 2. Relative growth of Mycobacterium tuberculosis H37Ra in the presence of nisin A and lacticin 3147.

Fig. 3. Relative growth of Mycobacterium kansasii CIT11/06 in the presence of nisin A and lacticin 3147.

Fig. 4. Relative growth of Mycobacterium avium subsp. paratuberculosis ATCC 19698 in the presence of nisin A and lacticin 3147. 


\section{Table 1}

$\mathrm{MIC}_{90}$ values of lacticin 3147 and nisin against pathogenic mycobacteria

Lantibiotic $\quad \mathrm{MIC}_{90}(\mathrm{mg} / \mathrm{L})$

M. tuberculosis H37Ra M. kansasii CIT11/06 MAP ATCC 19698

Lacticin $3147 \quad 7.5( \pm 0.36)$

$60( \pm 0.75)$

$15( \pm 0.30)$

Nisin $\quad>60( \pm 0.18)$

$60( \pm 0.13)$

$>60( \pm 2.02)$

$\mathrm{MIC}_{90}$, lowest concentration of lantibiotic that prevented growth of $>90 \%$ of the

bacterial population; MAP, Mycobacterium avium subsp. paratuberculosis. 


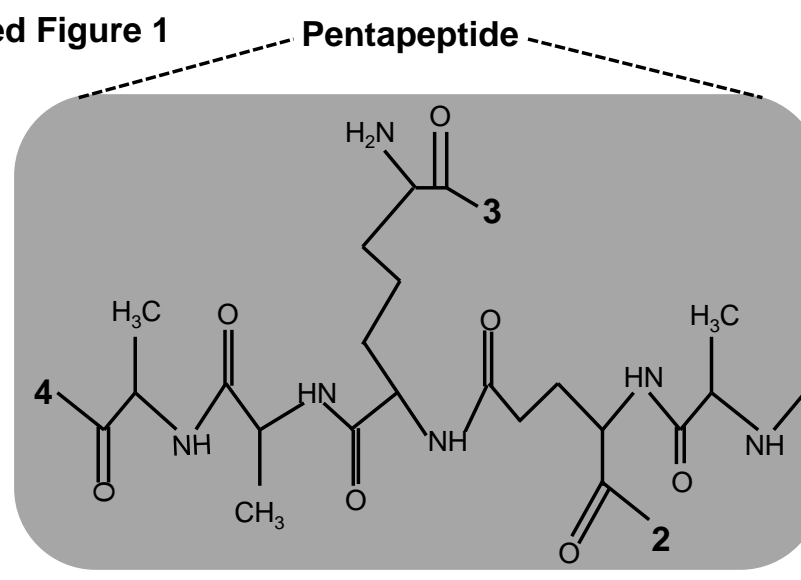

Modifications

$\mathbf{1}=\mathrm{H}, \mathrm{COCH}_{3}(\mathrm{~N}$-acetyl) or $\mathrm{COCH}$ ( $N$-glycol $)$

$2=\mathrm{OH}, \mathrm{NH}_{2}$ or $\mathrm{OCH}_{3}$

$3=\mathrm{OH}, \mathrm{NH}_{2}$ or $\mathrm{OCH}_{3}$

$4=\mathrm{OH}, \mathrm{NH}_{2}$ or $\mathrm{OCH}_{3}$

$\mathbf{5}=$ Deca-, hepta- and octa-prenyl phosphate
(Pol-P carrier)

Pyrophosphate

\section{NAG}

Hor

Capsule

polysaccharides

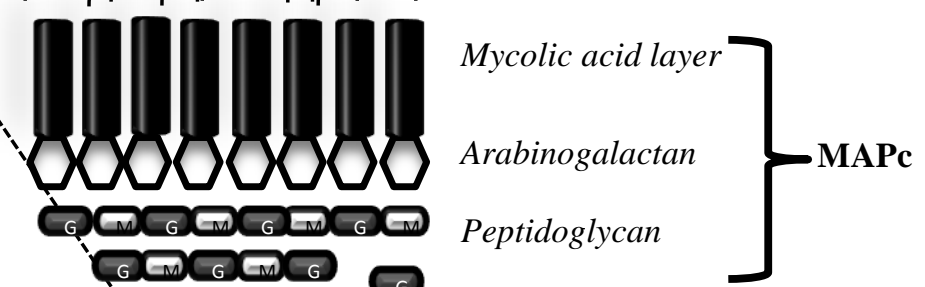

NAM
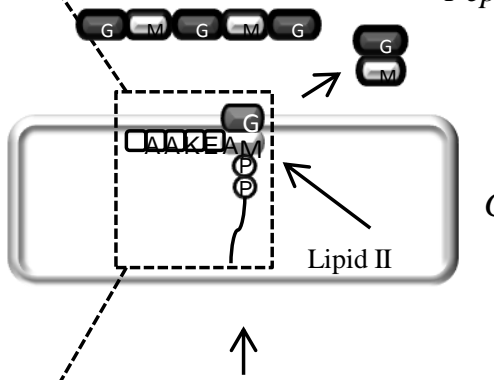

Cytoplasmic membrane

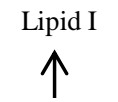

Cytoplasm

UDP-MurNAc-pentapeptide

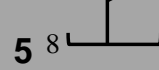

\begin{tabular}{|c|c|}
\hline $\begin{aligned} G & =\text { NAM } \\
G & =\text { NAG } \\
& =\text { Pyrophosphate }\end{aligned}$ & $\begin{aligned} A & =\text { Alanine } \\
\text { E } & =\text { Glutamic acid } \\
& =\text { Lysine }\end{aligned}$ \\
\hline
\end{tabular}




\section{Edited Figure 3}

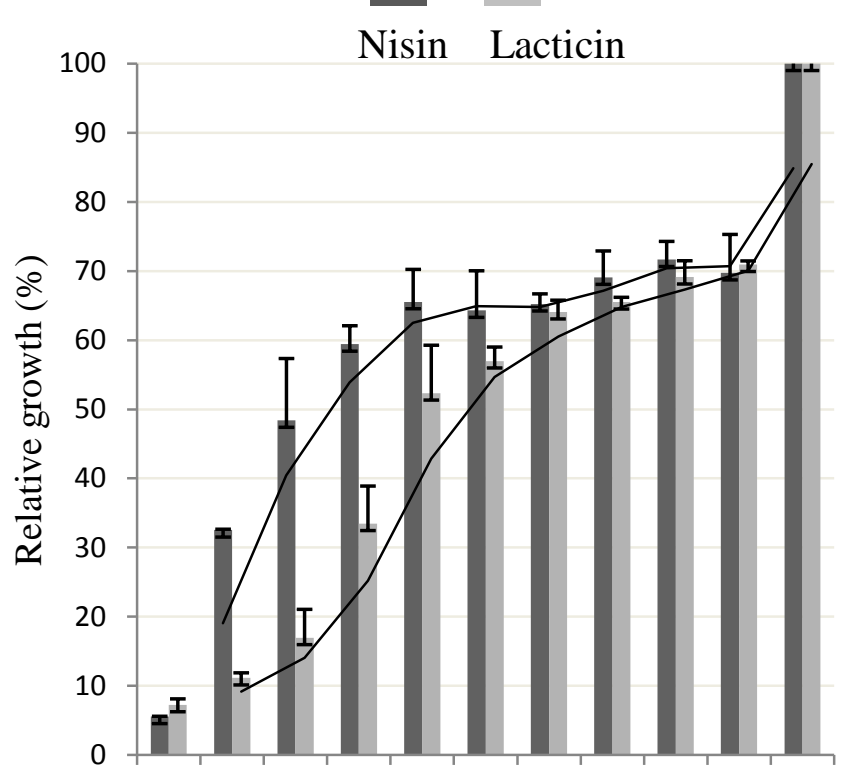

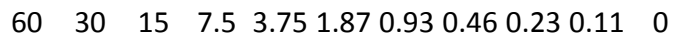

Concentration of lantibiotic (mg/L) 
